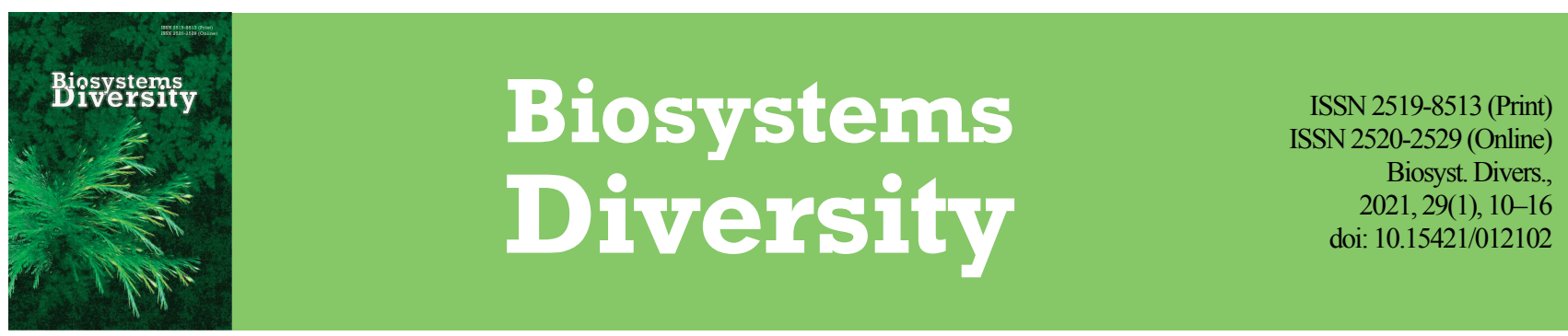

\title{
Long-term dynamics of photosynthetic pigments in plankton of a large plains reservoir
}

\author{
N. M. Mineeva \\ Papanin Institute for Biology of Inland Waters Russian Academy of Sciences, Borok, Russia \\ Article info \\ Received 03.01.2021 \\ Mineeva, N. M. (2021). Long-term dynamics of photosynthetic pigments in plankton of a large plains reservoir. Biosystems Diversity, \\ 29(1), 10-16. doi:10.15421/012102
}

Received in revised form 01.02 .2021

Accepted 02.02.2021

Papanin Institute

for Biology of Inland

Waters Russian Academy

of Sciences, 109, Borok,

Yaroslavkaya obl.

152742, Russia.

Tel.: +7-910-814-12-43.

E-mail:mineeva@ibiw.ru

Long-term observations are necessary to analyze and predict changes occurring in biological communities under global and regional climatic changes. The data on seasonal and long-term dynamics of chlorophyll in plankton of the Rybinsk Reservoir (Upper Volga, Russia) obtained in May - October 2009-2019 at six standard stations using the fluorescence method are presented. In the years with contrasting hydroclimatic conditions and water regime, the chlorophyll content varied from 1-3 to $>100 \mu \mathrm{g} / \mathrm{L}$. The significant variability of mean seasonal values ( $7.9 \pm 0.5 \mu \mathrm{g} / \mathrm{L}$ in 2009 to $27.6 \pm 1.7 \mu \mathrm{g} / \mathrm{L}$ in 2013 with variation coefficients of 52-134\%) indicates the low resistance of the community. The total chlorophyll content is associated with the development of three main phytoplankton divisions i.e., diatoms, cyanoprokaryots, and green algae. The trophic status of the reservoir was characterized as mesotrophic in 2009 and 2017, eutrophic in 2011-2014, and moderately eutrophic in other years. In the long-term seasonal cycle of phytoplankton, there are five periods with stable temperature conditions and transparency, but variable chlorophyll content. A moderate positive relationship was found between the seasonal dynamics of chlorophyll and water temperature, but a moderate negative relationship with transparency. The priority factors regulating the long-term dynamics of chlorophyll include the NAO indices, Wolf numbers, temperature, and underwater light conditions, as well as the inflow volume and water level. Water regime limits the development of phytoplankton.

Keywords: chlorophyll; phytoplankton; algal divisions; fluorescent method; environmental factors; long-term observations.

\section{Introduction}

It is well known that global climatic changes that have a significant impact on the structure and dynamics of biological communities of aquatic ecosystems (Adrian et al., 2009; Bertani et al., 2016; Özkan et al., 2016) continue to take place the beginning of the XXI century (Vtoroy, 2014). An increase in temperature is considered as a eutrophication factor that changes the availability of nutrients, promotes increase in the internal phosphorus load, as well as a more abundant and prolonged vegetation of cyanoprokaryotes (blue-green algae) (Jeppesen et al., 2005; Winder \& Hunter, 2008). To analyze and predict changes occurring in biological communities under these conditions, long-term observations which are carried out in many water bodies of the world (Ruggiu et al., 1998; Kangur et al., 2002; Chen et al., 2003; Babanazarova \& Lyashenko, 2007; Canfield et al., 2018; Lamont et al., 2019; Gao et al., 2020) are required. Photosynthetic pigments, which are the universal ecological and physiological characteristics of the development and photosynthetic activity of algae, as well as the ecological state of water bodies, are widely used in the study of the autotrophic community in aquatic ecosystems. The main plant pigment, chlorophyll $a(\mathrm{CHL})$, is a physiological marker that effectively indicates changes in the external environment.

The study of plant pigments in the water of the Rybinsk Reservoir has been carried out in IBIW RAS since the middle of the 20th century using the standard spectrophotometric method (SCOR-UNESCO, 1966). Longterm data have made it possible to study the seasonal and interannual dynamics of pigments, its relationship with regional and global environmental factors (Pautova \& Rosenberg, 1999; Kopylov, 2001; Sygareva et al., 2016; Lazareva, 2018). In 2009, we began additionally use fluorescent diagnostics, which allowed us to determine the chlorophyll content directly in natural water, obtain a number of phytoplankton characteristics without damaging its integrity, and quickly analyze a large data set (Mineeva, 2016; Mineeva \& Semadeni, 2020). Differentiated determination of chlorophyll in cyanoprokaryotes, diatoms and green algae made it possible to obtain new data on the seasonal and interannual dynamics of large taxonomic groups of phytoplankton, their contribution to the total chlorophyll content and their relationship with environmental factors in the years with different hydroclimatic conditions. The objective of this work was a comparative analysis of these data, which continue and supplement a long-term series of observations.

\section{Materials and methods}

The data were collected at six standard stations in the Rybinsk Reservoir (Fig. 1) during the growing seasons of 2009-2019 with a frequency of 1-2 times a month.

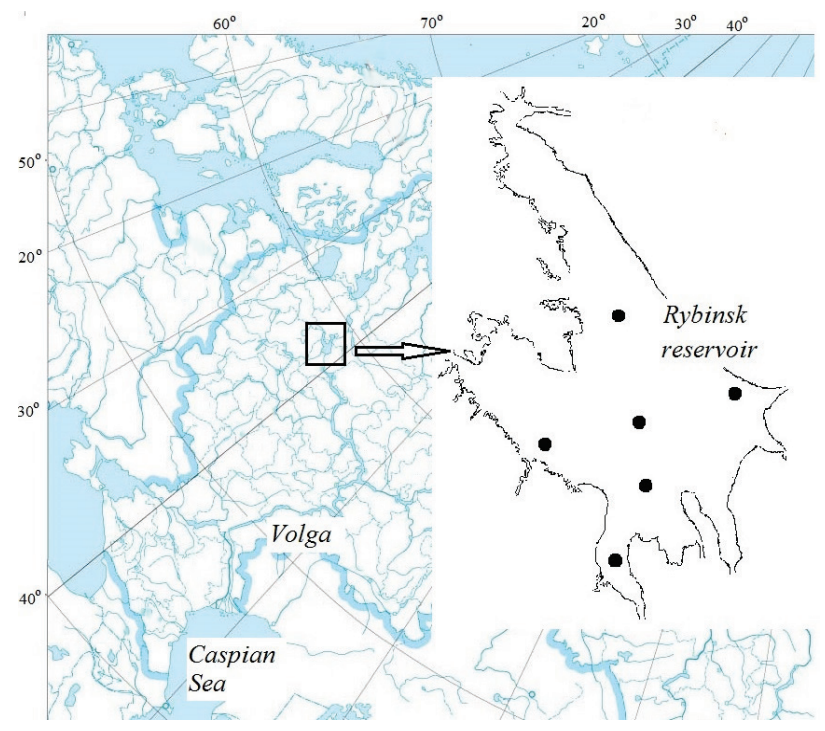

Fig. 1. Location of observation stations in the Rybinsk Reservoir

The samples were taken with a $1 \mathrm{~m}$ Elgmork bathometer from the entire water column $(0 \mathrm{~m}$ - bottom). During the study period, more than 500 observations were made at the reservoir stations and more than 940 sam- 
ples were taken for the analysis of pigments. Chlorophyll $a$ was determined by the fluorescence method, which makes it possible to estimate the total amount of pigment ( $\Sigma \mathrm{CHL})$ by its content in the main representatives of freshwater phytoplankton - cyanoprokaryotes, diatoms, and green algae $\left(\mathrm{CHL}_{\mathrm{Cyan}}, \mathrm{CHL}_{\mathrm{Bac}}, \mathrm{CHL}_{\mathrm{Ch}}\right.$, respectively) (Gold et al., 1986). Chlorophyll fluorescence was measured on a stationary PFL-3004 fluorimeter made at the Krasnoyarsk State University. The analysis procedure was described by us earlier (Mineeva, 2016). To assess the state of the community, the plasticity index was used (Shashulovsky \& Mosiyash, 2010), which is numerically equal to the average value of the modules of $\Sigma \mathrm{CHL}$ correlation coefficients with the environmental parameters. Water temperature, transparency, and colour were measured at each station. Reservoir level and inflow data in Table 1 were taken from the website www.rushydro.ru/hydrology/informer/?date; the data on air temperature and rainfall - from the weather archive https://rp5.ru; NAO index and Wolf numbers - from www.cpc.ncep.noaa.gov/data/teledoc/nao.shtml and www.sws.bom.gov.au/Solar/1/6. The average long-term climatic, hydrophysical, and hydrochemical characteristics of the Rybinsk Reservoir are given based on the materials of monographs (Kopylov, 2001; Lazareva, 2018).

Rybinsk Reservoir (the third stage of the Volga River cascade), located in the southern taiga subzone $\left(58^{\circ} 00^{\prime}-59^{\circ} 05^{\prime} \mathrm{N}, 37^{\circ} 28^{\prime}-39^{\circ} 00^{\prime} \mathrm{E}\right)$, is a large relatively shallow water body of slow water exchange (with surface area of $4500 \mathrm{~km}^{2}$, average depth of $5.6 \mathrm{~m}$, and average coefficient of water exchange equaling 1.9 year $\left.^{-1}\right)$. The area of the reservoir is divided into four heterogeneous areas (reaches) occupied by water masses with specific hydrophysical and hydrochemical characteristics. Three reaches are located along the flooded channels of the main tributaries, the Volga, Mologa and Sheksna rivers. River waters are gradually transformed into the water mass of the reservoir proper, which occupies a vast lake-like central part, the Main reach (Kuzin, 1972; Lazareva, 2018).

Standard software packages for a personal computer Statistic10 (StstSoft Inc., USA) were used for statistical data analysis. The data are given as mean value with standard error $(x \pm S E)$. To determine the relationships between chlorophyll content and environmental parameters we used Spearman rank coefficient $\left(\mathrm{r}_{\mathrm{S}}\right)$.

\section{Results}

The development of phytoplankton largely depends on hydrometeorological conditions. Although the observation years in the long-term series were characterized as warm, they differed significantly in weather patterns. The average annual air temperature exceeded the climatic norm of $3.7^{\circ} \mathrm{C}$. With the average temperature for May - October 2000-2019 equaling $13.6^{\circ} \mathrm{C}$, the growing season was the warmest in 2010 and the coldest in 2017 (Table 1).

Table 1

Hydroclimatic characteristics

in the Rybinsk Reservoir basin in the years of study

\begin{tabular}{rcccccccrrr}
\hline \multirow{2}{*}{ Year } & \multicolumn{2}{c}{$\begin{array}{c}\text { Air tempe- } \\
\text { rature, }{ }^{\circ} \mathrm{C}\end{array}$} & \multicolumn{2}{c}{$\begin{array}{c}\text { Precipitations, } \\
\mathrm{mm}\end{array}$} & $\begin{array}{c}\text { Inflow, } \\
\mathrm{km}^{3}\end{array}$ & $\begin{array}{c}\text { Level, } \\
\mathrm{mBS}\end{array}$ & $\begin{array}{c}\text { Wolf } \\
\text { numbers }\end{array}$ & \multicolumn{2}{c}{$\begin{array}{c}\text { NAO } \\
\text { index }\end{array}$} \\
\cline { 2 - 11 } & $\mathrm{V}-\mathrm{X}$ & Year & $\mathrm{V}-\mathrm{X}$ & Year & $\mathrm{V}-\mathrm{X}$ & $\mathrm{V}-\mathrm{X}$ & $\mathrm{V}-\mathrm{X}$ & Winter & Year \\
\hline 2009 & 13.4 & 5.0 & 370 & 662 & 18.47 & 101.19 & 5 & 0.34 & -2.92 \\
2010 & 14.9 & 4.4 & 503 & 831 & 12.47 & 101.05 & 25 & -5.90 & -13.8 \\
2011 & 14.4 & 5.1 & 372 & 627 & 11.92 & 101.05 & 81 & -1.42 & 3.52 \\
2012 & 13.7 & 4.2 & 558 & 859 & 14.95 & 101.29 & 84 & 5.38 & -5.47 \\
2013 & 14.4 & 5.5 & 285 & 589 & 13.40 & 100.85 & 94 & -1.54 & 2.52 \\
2014 & 13.7 & 5.7 & 315 & 503 & 4.54 & 99.81 & 114 & 3.38 & 2.24 \\
2015 & 13.4 & 6.1 & 464 & 647 & 14.26 & 100.32 & 70 & 6.42 & 5.20 \\
2016 & 14.1 & 5.4 & 435 & 717 & 14.59 & 101.15 & 40 & 4.67 & -0.46 \\
2017 & 12.1 & 4.8 & 474 & 752 & 23.00 & 101.63 & 22 & 2.70 & 2.71 \\
2018 & 14.5 & 4.9 & 473 & 689 & 16.77 & 100.93 & 7 & 2.97 & 13.00 \\
2019 & 13.1 & 6.1 & 497 & 799 & 15.16 & 100.86 & 4 & 2.72 & -3.82 \\
\hline
\end{tabular}

The heating of the water column is related to the air temperature with coefficient of determination $\mathrm{R}^{2}=0.74$. The water temperature in May October 2016-2019 was close to the long-term average $\left(13.6^{\circ} \mathrm{C}\right)$, lower than the average for $2000-2012\left(15.0^{\circ} \mathrm{C}\right)$, but exceeded the average in 2009-2015. The maximum water temperature in summer was generally $20-24^{\circ} \mathrm{C}$, reaching abnormally high values $\left(25-27^{\circ} \mathrm{C}\right)$ in 2010 and 2018
(Table 2). The annual amount of precipitation generally corresponded to the climatic norm $(436-887 \mathrm{~mm}$, average $655 \mathrm{~mm})$. The average amount of precipitations for May - October 2000-2019 was $395 \mathrm{~mm}, 72 \%$ and $80 \%$ of this amount fell in 2013 and 2014, 140\% in 2012. According to the water content, 10 out of 11 years of observations referred to the highwater period with the inflow volume significantly exceeding the norm in 2017. Only in the extremely low-water year of 2014, did the inflow sharply decrease. In accordance with the inflow volume, the reservoir level was minimal in 2014 and exceeded the normal level of $101 \mathrm{~m} \mathrm{BS}$ in 2009 2012, 2016, 2017. Judging by the dynamics of Wolf numbers, the observations covered an 11-year cycle of solar activity (Table 1). The transparency and colour of the water were characterized by values typical for the reservoir (Table 2). Over the 11-year observation period, there occurred a moderate linear increase in the mean annual air temperature $\left(R^{2}=0.21\right)$, winter and annual NAO indices $\left(R^{2}=0.31\right.$ and 0.25$)$, but a decrease in the average seasonal and especially summer water temperature $\left(\mathrm{R}^{2}=0.27\right.$ and 0.56$)$.

Table 2

Temperature, water transparency and colour in the Rybinsk Reservoir in the years of study

\begin{tabular}{|c|c|c|c|c|c|c|c|}
\hline \multirow{3}{*}{ Year } & \multicolumn{3}{|c|}{ Temperature, ${ }^{\circ} \mathrm{C}$} & \multicolumn{2}{|c|}{ Transparency, $\mathrm{m}$} & \multicolumn{2}{|c|}{ Color, Cr-Co degree } \\
\hline & \multirow{2}{*}{ Limits } & \multicolumn{2}{|c|}{$x \pm S E$} & \multirow{2}{*}{ Limits } & \multirow{2}{*}{$x \pm S E$} & \multirow{2}{*}{ Limits } & \multirow{2}{*}{$x \pm S E$} \\
\hline & & Summer & $\mathrm{V}-\mathrm{X}$ & & & & \\
\hline 2009 & $6.4-22.8$ & $19.9 \pm 0.4$ & $16.9 \pm 0.6$ & $1.0-2.7$ & $1.34 \pm 0.05$ & & $55 \pm 1$ \\
\hline 2010 & & 0.8 & 16.1 & & & & \pm 1 \\
\hline 2011 & $7.1-24.2$ & $22.2 \pm 0.5$ & $18.2 \pm 0.6$ & $0.6-2.1$ & $0.99 \pm 0.03$ & $35-80$ & $51 \pm 1$ \\
\hline 2012 & 3.3 & 20.3 & $16.7=$ & $0.7-1.5$ & 1.08 & & $50 \pm 2$ \\
\hline 2013 & $6.6-23.8$ & $20.6 \pm 0.6$ & $17.5 \pm 0.6$ & $0.5-1.2$ & 0.86 & 100 & $62 \pm 2$ \\
\hline 2014 & $7.2-24.0$ & $19.5 \pm 0.6$ & $17.1 \pm$ & $0.4-1.7$ & 0.05 & & $41 \pm 1$ \\
\hline 2015 & $11.8-19.6$ & $17.4 \pm 0.4$ & $15.5 \pm 0.5$ & $0.7-1.8$ & 0.07 & & $40 \pm 2$ \\
\hline 2016 & $1.1-23.5$ & $21.2 \pm 0.5$ & $13.9 \pm 0.9$ & $0.7-2.1$ & $1.12 \pm 0.04$ & $40-140$ & $57 \pm 3$ \\
\hline 2017 & $4.4-20.6$ & $17.7 \pm 0.4$ & $13.4 \pm 0.6$ & $0.8-1.7$ & $1.20 \pm 0.03$ & & $85 \pm 2$ \\
\hline 2018 & $3.5-25.0$ & $21.0 \pm 0.4$ & $13.4 \pm 0.9$ & $0.5-2.1$ & $1.09 \pm 0.04$ & $40-100$ & $60 \pm 2$ \\
\hline 2019 & $5.8-19.8$ & $18.3 \pm 0.2$ & $14.0 \pm 0.7$ & $0.7-2.1$ & $1.36 \pm 0.04$ & $35-90$ & $52 \pm 2$ \\
\hline
\end{tabular}

The $\Sigma$ CHL content varied over a wide range. The minimum values $>1-3 \mu \mathrm{g} / \mathrm{L}$ were shown by $\sim 16 \%$ of the total samples, the ranges of $3-$ $10 \mu \mathrm{g} / \mathrm{L}$ and $10-30 \mu \mathrm{g} / \mathrm{L}$ were $36 \%$ and $37 \%$, the higher concentrations were $\sim 10 \%$ and only $1.5 \%$ of them exceeded $60 \mu \mathrm{g} / \mathrm{L}$ (Fig. 2).

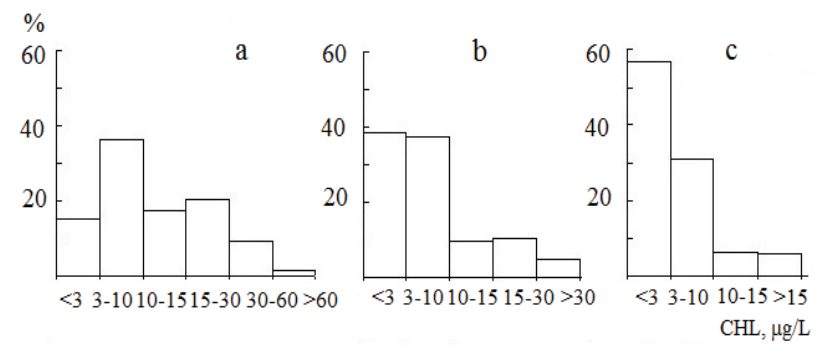

Fig. 2. Occurrence rate of $\Sigma \mathrm{CHL}(a), \mathrm{CHL}_{\mathrm{Cyan}}(b)$, and $\mathrm{CHL}_{\mathrm{Bac}}(c)$ in the Rybinsk Reservoir in 2009-2019

( $\%$ of the total observation number $n=948$ )

The seasonal dynamics of $\Sigma \mathrm{CHL}$, that is dynamics of phytoplankton biomass, were characterized by two or three peaks with differences in the timing of the onset, the duration, and the ratio of values in different years (Fig. 3).

The spring peak with average $\Sigma \mathrm{CHL}$ concentrations of $13-32 \mu \mathrm{g} / \mathrm{L}$ was recorded at the water temperatures of $6-9^{\circ} \mathrm{C}$ to $11-15^{\circ} \mathrm{C}$ in May early June 2011, 2012, 2016, 2018, 2019; summer peak (27-45 $\mu \mathrm{g} / \mathrm{L})-$ during the period of maximum warming up in July - September 2010 2014, 2016, 2018; the most noticeable autumn peak (30 $\mu \mathrm{g} / \mathrm{L})$ in October 2014 at the temperature of $7.5^{\circ} \mathrm{C}$. Two seasonal peaks at a lower $\Sigma \mathrm{CHL}$ content were observed in 2009 and 2017. The maximum summer and spring values are comparable in 2009, 2011, 2012, 2016 and 2017; the summer peak dominated the seasonal dynamics in 2010, 2013, 2018, while in 2019 it was less than the spring one. The spring and summer maxima are separated by an early summer phytoplankton depression, during which the $\Sigma \mathrm{CHL}$ content decreased against the background of the seasonal change in communities. 

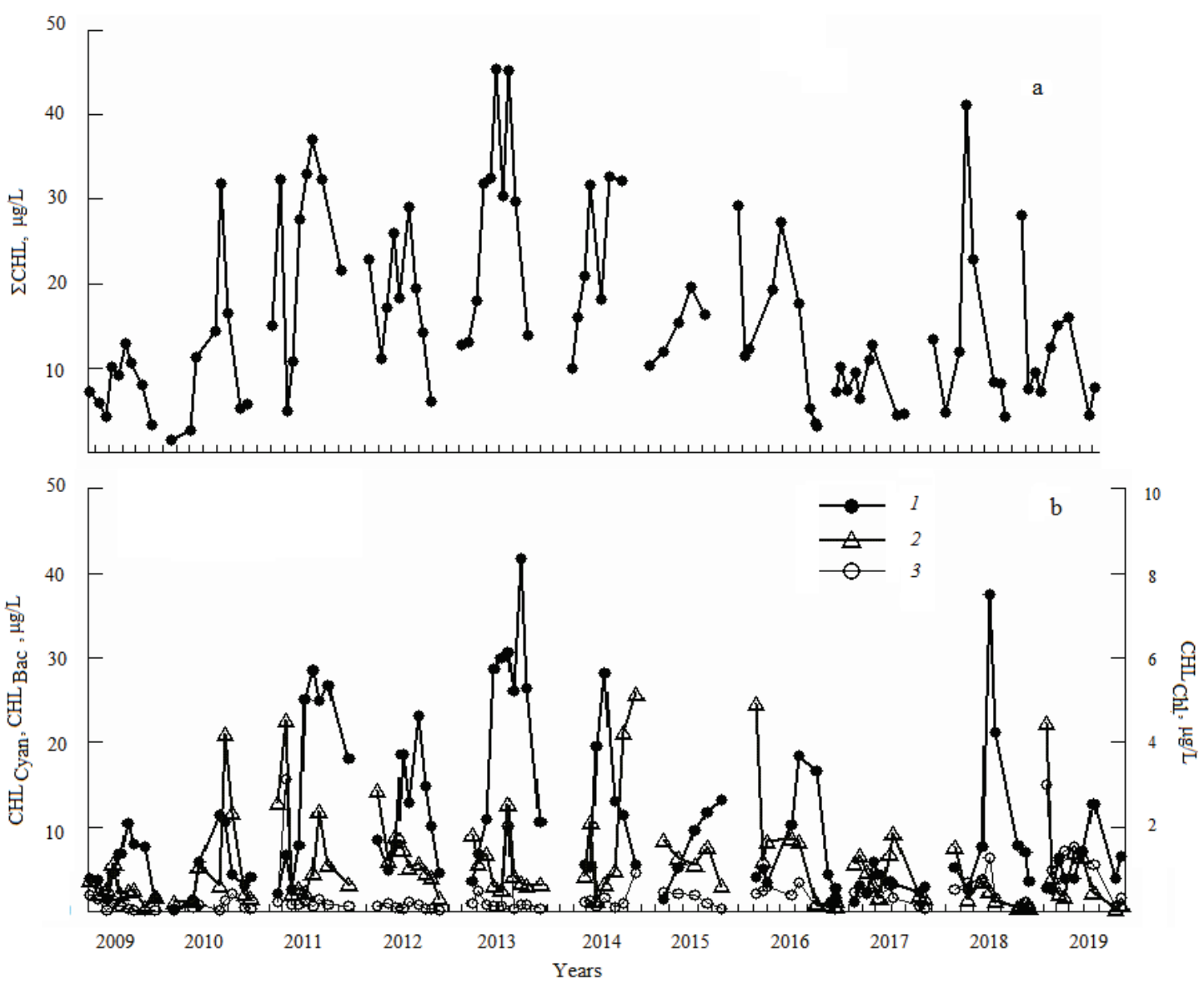

Fig. 3. Seasonal and long-term dynamics of chlorophyll in the Rybinsk Reservoir: $a-\Sigma \mathrm{CHL}, b-\mathrm{CHL}_{\mathrm{Cyan}}$ and $\mathrm{CHL}_{\mathrm{Bac}}$; left axis $-\mathrm{CHL}_{\mathrm{Cyan}}(1)$ and $\mathrm{CHL}_{\mathrm{Bac}}(2)$, right axis $-\mathrm{CHL}_{\mathrm{Chl}}(3)$, mean values

The analysis of 11-year data revealed five periods in the seasonal cycle of $\Sigma \mathrm{CHL}$. Each period is characterized by uniform temperature conditions and transparency. The average values of temperature and transparency for each period are equal to their medians. The $\Sigma \mathrm{CHL}$ variability is minimal in early summer with the seasonal change of communities but is significantly higher during the spring and summer phytoplankton maxima; the arithmetic averages in all cases exceed the medians by $25-30 \%$. The development of phytoplankton in spring and early summer is accompanied by a decrease in the content of mineral nitrogen, while changes in mineral phosphorus and total forms of biogenic elements during the entire growing season are small (Table 3 ).

Table 3

Conditions for the formation of phytoplankton seasonal dynamics in the Rybinsk Reservoir in 2009-2019 ( $\mathrm{x} \pm$ SE; in brackets - coefficient of variation (\%) / median; $\mathrm{n}$-observation number)

\begin{tabular}{lccccc}
\hline \multicolumn{1}{c}{ Parameter } & Spring & $\begin{array}{c}\text { Early } \\
\text { summer }\end{array}$ & $\begin{array}{c}\text { Mid } \\
\text { summer }\end{array}$ & $\begin{array}{c}\text { Late } \\
\text { summer }\end{array}$ & Autumn \\
\hline$n$ & 54 & 92 & 218 & 86 & 89 \\
$\Sigma \mathrm{CHL}$, & $15.9 \pm 1.9$ & $8.9 \pm 0.6$ & $20.4 \pm 1.0$ & $21.2 \pm 1.6$ & $6.3 \pm 0.5$ \\
$\mu \mathrm{g} / \mathrm{L}$ & $(90 / 12.2)$ & $(58 / 7.1)$ & $(73 / 16.2)$ & $(72 / 17.0)$ & $(73 / 5.1)$ \\
Temperature, & $9.9 \pm 0.5$ & $15.7 \pm 0.3$ & $20.4 \pm 0.2$ & $15.0 \pm 0.2$ & $7.2 \pm 0.3$ \\
${ }^{\circ} \mathrm{C}$ & $(38 / 9.7)$ & $(19 / 16.2)$ & $(11 / 20.2)$ & $(12 / 14.3)$ & $(36 / 7.7)$ \\
Transparency, & $1.20 \pm 0.03$ & $1.11 \pm 0.03$ & $1.13 \pm 0.02$ & $1.06 \pm 0.04$ & $1.12 \pm 0.04$ \\
$\mathrm{~m}$ & $(24 / 1.15)$ & $(25 / 1.0)$ & $(23 / 1.10)$ & $(32 / 1.0)$ & $(37 / 1.0)$ \\
$\mathrm{N}_{\text {min }}, \mathrm{mg} / \mathrm{L}^{*}$ & 0.45 & 0.31 & 0.19 & 0.14 & 0.14 \\
$\mathrm{P}_{\text {min, }} \mu \mathrm{gg} / \mathrm{L}^{*}$ & 21 & 18 & 21 & 26 & 65 \\
$\mathrm{TN}, \mathrm{mg} / \mathrm{L}^{*}$ & 0.99 & 1.02 & 0.91 & 1.02 & 0.93 \\
$\mathrm{TP}, \mu \mathrm{Lg} \mathrm{L}^{*}$ & 48 & 48 & 64 & 67 & 140 \\
\hline
\end{tabular}

Note: * data obtained in 2001-2012 (Lazareva, 2018).

The fluorescence method makes it possible to estimate chlorophyll content of the three main divisions of algae (Table 4). In most cases concentration of $\Sigma \mathrm{CHL}$ was determined by the amount of $\mathrm{CHL}_{\mathrm{Cyan}}$; in 2010 ,
2016, 2017, 2019 the dominant influence belonged to $\mathrm{CHL}_{\mathrm{Bac}}$, in 2017 2019 the role of $\mathrm{CHL}_{\mathrm{Chl}}$ was noticeable as well, and in $2011 \mathrm{\Sigma CHL}$ equally depended on all three components (Table 5).

Table 4

Chlorophyll total amount and chlorophyll content in the main divisions of algae in plankton of the Rybinsk Reservoir in the years of study $(\mathrm{x} \pm \mathrm{SE}$; in brackets - coefficient of variation $(\%) /$ median $)$

\begin{tabular}{|c|c|c|c|c|c|c|c|}
\hline \multirow{2}{*}{ Year } & \multirow{2}{*}{$\frac{\Sigma \mathrm{CHL}}{\mu \mathrm{g} / \mathrm{L}}$} & \multicolumn{2}{|c|}{$\mathrm{CHL}_{\mathrm{Cyan}}$} & \multicolumn{2}{|c|}{$\mathrm{CHL}_{\mathrm{Bac}}$} & \multicolumn{2}{|c|}{$\mathrm{CHL}_{\mathrm{Ch}}$} \\
\hline & & $\mathrm{gg} / \mathrm{L}$ & $\%$ & $\mathrm{dg} / \mathrm{L}$ & $\%$ & $\mu \mathrm{g} / \mathrm{L}$ & $\%$ \\
\hline & $\begin{array}{l}7.9 \pm 0.5 \\
(75 / 6.6)\end{array}$ & & $63.3 \pm 1.9$ & & $35.1 \pm 2.0$ & & \\
\hline 10 & $\begin{array}{l}11.3 \pm \\
(117 /\end{array}$ & & $46.2 \pm 2.5$ & & $51.5 \pm 2.4$ & $\begin{array}{l}0.03 \\
06)\end{array}$ & \\
\hline & $\begin{array}{l}24.1 \pm 2.0 \\
(102 / 16.6)\end{array}$ & $\begin{array}{l} \pm 1.4 \\
10.7)\end{array}$ & $60.2 \pm 2.4$ & $\begin{array}{l}7.5 \\
(169\end{array}$ & $37.8 \pm 2.3$ & $\begin{array}{l}0.19 \\
.17)\end{array}$ & $1.9 \pm 0$ \\
\hline & $\begin{array}{c}18.4 \pm 0.9 \\
(59 / 17.2)\end{array}$ & & $61.3 \pm 1.6$ & & $37.8 \pm 1.6$ & & $0.9 \pm 0$ \\
\hline & $\begin{array}{l}27.6 \pm 1.7 \\
(79 / 22.0)\end{array}$ & & $70.0 \pm 1.8$ & $\begin{array}{l}5.5 \pm \\
(99 /\end{array}$ & $28.1 \pm 1.8$ & & \\
\hline & $\begin{array}{l}20.9 \pm \\
(104 / 1\end{array}$ & 2) & $59.6 \pm 2.9$ & $\begin{array}{l}7.2 \pm \\
(124\end{array}$ & $38.9 \pm 2.9$ & .05 & \\
\hline & $\begin{array}{l}14.8 \pm 1.0 \\
(52 / 14.7)\end{array}$ & & $50.0 \pm 3.9$ & $\begin{array}{c}6.2 \pm 0.6 \\
(83 / 4.5)\end{array}$ & $47.0 \pm 3.6$ & $\begin{array}{l}.03 \\
9)\end{array}$ & 0 \\
\hline & $\begin{array}{l}13.0 \pm 1.3 \\
(102 / 9.6)\end{array}$ & $\begin{array}{l}6.0 \\
(11\end{array}$ & $54.8 \pm 2.3$ & $\begin{array}{c}6.6 \pm 1.0 \\
(160 / 2.9)\end{array}$ & & $\begin{array}{l}0.05 \\
19)\end{array}$ & 3.8 \\
\hline 2017 & $\begin{array}{l}7.8 \pm 0.6 \\
(88 / 6.3)\end{array}$ & & $44.6 \pm 2.1$ & $\begin{array}{l}4.4 \pm 0.5 \\
(139 / 2.4)\end{array}$ & $50.5 \pm 2.0$ & $\begin{array}{r}0.35 \\
(95\end{array}$ & 7. \\
\hline 2018 & $\begin{array}{c}13.6 \pm 1.6 \\
(134 / 7.9)\end{array}$ & $\begin{array}{l}10.9 \pm 1.6 \\
(159 / 5.6)\end{array}$ & $70.4 \pm 2.4$ & $\begin{array}{l}2.4 \pm 0.4 \\
(174 / 1.0)\end{array}$ & $23.5 \pm 2.2$ & $\begin{array}{l}0.47 \\
(110\end{array}$ & $r_{1}$ \\
\hline 2019 & $\begin{array}{l}11.9 \pm 1.0 \\
(92 / 9.0)\end{array}$ & $\begin{array}{l}5.7 \pm 0.5 \\
(110 / 3.8)\end{array}$ & $53.0 \pm 2.7$ & $\begin{array}{l}5.0 \pm 0.8 \\
(170 / 2.0)\end{array}$ & $34.6 \pm 2.2$ & $\begin{array}{c}1.24 \pm 0.10 \\
(98 / 0.97)\end{array}$ & \\
\hline
\end{tabular}

The amount of $\mathrm{CHL}_{\mathrm{Cyan}}$ and $\mathrm{CHL}_{\mathrm{Bac}}$ did not correlate. With a wide range of values, the minimum chlorophyll content of each algal division did not exceed $1 \mu \mathrm{g} / \mathrm{L}$. The predominant values of $\mathrm{CHL}_{\mathrm{Bac}}$ and $\mathrm{CHL}_{\mathrm{Cyan}}$ 
are limited to $10 \mu \mathrm{g} / \mathrm{L}$ (Fig. 2). In different years, the highest concentration of $\mathrm{CHL}_{\text {Bac }}$ reached 18.4-92 $\mu \mathrm{g} / \mathrm{L}, \mathrm{CHL}_{\text {Cyan }} 25.1-130 \mu \mathrm{g} / \mathrm{L}, \mathrm{CHL}_{\mathrm{Chl}} 1-$ $4 \mu \mathrm{g} / \mathrm{L}$ and $16 \mu \mathrm{g} / \mathrm{L}$ in 2011 . A noticeable amount of $\mathrm{CHL}_{\text {Cyan }}$ was present in the reservoir throughout the growing season, with the highest occurring during the summer phytoplankton maximum. The seasonal dynamics of $\mathrm{CHL}_{\mathrm{Bac}}$ was characterized by a spring peak in all the years, and by the second autumn peak in 2014. In 2010, 2011, 2013, 2015, 2017, high concentrations of $\mathrm{CHL}_{\mathrm{Bac}}$ were also noted in summer. At low $\mathrm{CHL}_{\mathrm{Ch}}$ concentrations, its seasonal dynamics are not pronounced (Fig. 3). $\mathrm{CHL}_{\mathrm{Bac}}$ and $\mathrm{CHL}_{\mathrm{Cyan}}$ made the main contribution to $\mathrm{ECHL}$, their ratio varied in different years. The values averaged over the growing season show that $\mathrm{CHL}_{\text {Cyan }}$ more often prevailed in the $\Sigma \mathrm{CHL}$ pool, particularly in 2013 and 2018. The difference between the shares of $\mathrm{CHL}_{\mathrm{Cyan}}$ and $\mathrm{CHL}_{\mathrm{Bac}}$ was not large in 2010 and 2015-2017, the percentage of $\mathrm{CHL}_{\mathrm{Chl}}$ increased in 2017-2019 (Table 4).

Table 5

Correlation coefficients of $\Sigma \mathrm{CHL}$ with $\mathrm{CHL}_{\mathrm{Cyan},} \mathrm{CHL}_{\mathrm{Bac}}$, and $\mathrm{CHL}_{\mathrm{Chl}}$ in the years of study $\left(\mathrm{r}_{0.05}>0.28 ; \mathrm{n}\right.$ - observation number $)$

\begin{tabular}{ccccc}
\hline Year & $n$ & CHL $_{\text {Cyan }}$ & CHL $_{\text {Bac }}$ & CHL $_{\text {Chl }}$ \\
\hline 2009 & 53 & 0.90 & 0.49 & 0.10 \\
2010 & 46 & 0.51 & 0.89 & 0.43 \\
2011 & 53 & 0.79 & 0.71 & 0.69 \\
2012 & 53 & 0.88 & 0.54 & 0.29 \\
2013 & 60 & 0.96 & 0.35 & 0.44 \\
2014 & 34 & 0.89 & 0.33 & 0.25 \\
2015 & 61 & 0.76 & 0.41 & 0.23 \\
2016 & 153 & 0.67 & 0.81 & 0.52 \\
2017 & 270 & 0.39 & 0.89 & 0.70 \\
2018 & 136 & 0.97 & 0.27 & 0.71 \\
2019 & 163 & 0.47 & 0.82 & 0.71 \\
\hline
\end{tabular}

The average $\Sigma \mathrm{CHL}$ content varied from the minimum $<10 \mu \mathrm{g} / \mathrm{L}$ in 2009 and 2017 to the maximum 18.4-27.6 in 2011-2014 and was characterized by intermediate values in other years. The minimum and maximum $\mathrm{CHL}_{\mathrm{Cyan}}$ values also were noted in these years. The more stable average content of $\mathrm{CHL}_{\mathrm{Bac}}$ was generally $5.0-7.5 \mu \mathrm{g} / \mathrm{L}$ and decreased in $2009,2017,2018$. In recent years, the concentration of $\mathrm{CHL}_{\mathrm{Chl}}$ has increased (Table 4). For all of the above indicators, the long-term dynamics of their mean values for the growing season is not linear and is approximated by a polynomial relationship (Table 6).

\section{Table 6}

Approximation of long-term dynamics (2009-2019) of total chlorophyll and chlorophyll of the main divisions of algae in the Rybinsk Reservoir

\begin{tabular}{ccc}
\hline Parameter & Regression equation & $R^{2}$ \\
\hline$\Sigma C H L$ & $y=-8.80+17.55 x-2.96 x^{2}+0.14 x^{3}$ & 0.74 \\
CHL $_{\mathrm{Cyan}}$ & $y=-7.91+12.97 x-2.20 x^{2}+0.10 x^{3}$ & 0.55 \\
CHL $_{\text {Bac }}$ & $y=-0.27+3.96 x-0.64 x^{2}+0.03 x^{3}$ & 0.60 \\
CHL $_{\mathrm{Chl}}$ & $y=0.405-0.113 x+0.014 x^{2}$ & 0.60 \\
\hline
\end{tabular}

The pigment characteristics during the growing season of each year varied greatly. The coefficients of variation were $<100 \%$ in six of 11 cases for $\Sigma \mathrm{CHL}$, in five cases for $\mathrm{CHL}_{\mathrm{Cyan}}$, in three cases for $\mathrm{CHL}_{\mathrm{Bac}}$ and CHL Ch. Only in 2012 and 2015,was moderate variability of $\Sigma$ CHL noted, as well as lower variability of $\mathrm{CHL}_{\mathrm{Cyan}}$ and $\mathrm{CHL}_{\mathrm{Bac}}$ against the general background. For all data, the average values exceeded their medians: 1.2 1.9 times for $\Sigma \mathrm{CHL}$ and $\mathrm{CHL}_{\text {Cyan, }} 1.3$ to over 2.0 times for $\mathrm{CHL}_{\mathrm{Bac}}$ and $\mathrm{CHL}_{\mathrm{Chl}}$. Only in 2012 and 2015 are both characteristics equal for $\Sigma \mathrm{CHL}$ (Table 4).

In accordance with the average $\Sigma \mathrm{CHL}$ content, the trophic status of the reservoir is assessed as mesotrophic in 2009 and 2017, eutrophic in 2011-2014, and moderately eutrophic in other years. $\mathrm{CHL}_{\mathrm{Cyan}}$ and $\mathrm{CHL}_{\mathrm{Bac}}$ change in parallel with $\Sigma \mathrm{CHL}\left(\mathrm{R}^{2}=0.92\right.$ and 0.31$)$, while such a relationship was not revealed for $\mathrm{CHL}_{\mathrm{Chl}}$. When ranking all parameters by $\Sigma \mathrm{CHL}$, their regular increase is observed with an increase in trophic level. The relative content of $\mathrm{CHL}_{\text {Cyan }}$ increases with decrease in the proportion of $\mathrm{CHL}_{\mathrm{Bac}}$ and $\mathrm{CHL}_{\mathrm{Chl}}$. The coefficients of variation show that the variability of $\Sigma \mathrm{CHL}$ within the trophic categories ranges from insignificant in mesotrophic and eutrophic waters to moderate in oligotrophic waters; $\mathrm{CHL}_{\text {Cyan }}$ variability is moderate, $\mathrm{CHL}_{\mathrm{Bac}}$ variability is higher, and $\mathrm{CHL}_{\mathrm{Chl}}$ variability is maximal (Table 7).
Table 7

Change in the content of $\Sigma \mathrm{CHL}, \mathrm{CHL}_{\mathrm{Cyan}}, \mathrm{CHL}_{\mathrm{Bac}}$, and $\mathrm{CHL}_{\mathrm{Chl}}$ along the gradient of trophic state $(\mathrm{x} \pm \mathrm{SE}$; in brackets - coefficient of variation, $\% ; n$ - observation number)

\begin{tabular}{|c|c|c|c|c|c|c|}
\hline Parameter & $\begin{array}{l}\text { Oligo- } \\
\text { trophic }\end{array}$ & $\begin{array}{l}\text { Meso- } \\
\text { trophic }\end{array}$ & $\begin{array}{l}\text { Moderate } \\
\text { eutrophic }\end{array}$ & Eutrophic & $\begin{array}{l}\text { Poly- } \\
\text { trophic }\end{array}$ & $\begin{array}{l}\text { Hyper- } \\
\text { trophic }\end{array}$ \\
\hline$n$ & 204 & 490 & 246 & 365 & 124 & 72 \\
\hline$\Sigma \mathrm{CHL}, \mu \mathrm{g} / \mathrm{L}$ & $\begin{array}{c}1.7 \pm 0.1 \\
(42.2)\end{array}$ & $\begin{array}{r}6.1= \\
(31\end{array}$ & & & $\begin{array}{r}37.9= \\
(14\end{array}$ & \\
\hline $\mathrm{CHL}_{\text {Cyan }}, \mu \mathrm{g} / \mathrm{L}$ & $\begin{array}{c}0.9 \pm 0.1 \\
(69.5)\end{array}$ & $\begin{array}{r}3.3 \pm \\
(61 .\end{array}$ & $\begin{array}{r}7.7 \pm \\
(41\end{array}$ & $\begin{array}{r}12.8 \pm \\
(51 .\end{array}$ & $\begin{array}{c}25.6 \pm 1.0 \\
(48.3)\end{array}$ & $\begin{array}{c}49.7 \pm 3.6 \\
(64.4)\end{array}$ \\
\hline & & & & & & 69.8 \\
\hline $\mathrm{CHL}_{\mathrm{Bac}}, \mu \mathrm{g} / \mathrm{L}$ & $\begin{array}{c}0.7 \pm 0.1 \\
(71.5)\end{array}$ & $\begin{array}{c}2.6 \pm 0.1 \\
(73.4)\end{array}$ & $\begin{array}{r}4.1 \pm \\
(70 .\end{array}$ & $\begin{array}{c}7.8 \pm 0.3 \\
(77.3)\end{array}$ & $\begin{array}{c}11.3 \pm 0.9 \\
(94.5)\end{array}$ & $\begin{array}{c}19.7 \pm 2.6 \\
(120)\end{array}$ \\
\hline The same, $\%$ & & & & & 30.1 & 27.7 \\
\hline & $\begin{array}{c}0.12 \pm \\
0.01 \\
(103)\end{array}$ & $\begin{array}{c}0.30 \pm \\
0.02 \\
(128)\end{array}$ & $\begin{array}{l}0.0 \\
(15\end{array}$ & $\begin{array}{c}0.4 \\
0.4\end{array}$ & $\begin{array}{c}0.65 \pm \\
0.09 \\
(172)\end{array}$ & $\begin{array}{c}1.74 \pm \\
0.37 \\
(193)\end{array}$ \\
\hline The same, $\%$ & 7.2 & 4.9 & 3.1 & 1.9 & 1.7 & 2.4 \\
\hline
\end{tabular}

Assessment of the influence of environmental factors on the seasonal dynamics of phytoplankton reveals a moderate positive relationship between $\Sigma \mathrm{CHL}$ and water temperature in 2009, 2010, 2014, 2015, $2018\left(\mathrm{r}_{\mathrm{S}}=\right.$ $0.36-0.67)$, a moderate negative relationship with transparency in 2010 2015 , and with water colour in $2015\left(\mathrm{r}_{\mathrm{S}}=-0.40 \ldots-0.51\right)$; $\Sigma \mathrm{CHL}$ does not depend on the depth of the station. The community plasticity index calculated from the correlation coefficients varies from 0.09 in 2017 to 0.42 in 2015 , averaging $0.22 \pm 0.03$ over the entire study period. The example of 2010 shows that accounting for hydrochemical factors does not affect the assessment of the state of the community: the plasticity index is 0.26 for the general data for all years, 0.22 for the hydrochemical block, and 0.24 on average (Fig. 4).

In the long-term aspect, the relationship of chlorophyll with environmental factors is more pronounced. For the mean concentrations of $\Sigma \mathrm{CHL}$, a positive dependence on temperature, as well as on Wolf numbers, the index of solar activity, was revealed, whereas the water content (rainfall, inflow, water level) are the limiting factor. The $\Sigma \mathrm{CHL}$ content is negatively related to the transparency and colour of the water. A moderate positive correlation was obtained between $\Sigma \mathrm{CHL}, \mathrm{CHL}_{\mathrm{Cyan}}$ and the annual NAO index (Table 8).

Table 8

Correlation coefficients $\left(\mathrm{r}_{\mathrm{S}}\right)$ between the average chlorophyll content and environmental factors $\left(\mathrm{r}_{0.05}=0.45\right)$

\begin{tabular}{lcccc}
\hline \multicolumn{1}{c}{ Parameter } & $\Sigma \mathrm{CHL}$ & $\mathrm{CHL}_{\text {Cyan }}$ & $\mathrm{CHL}_{\text {Bac }}$ & CHL $_{\text {Chl }}$ \\
\hline Air temperature & 0.41 & 0.41 & 0.31 & 0.00 \\
Water temperature & 0.53 & 0.56 & 0.38 & -0.44 \\
Precipitation & -0.50 & -0.58 & -0.19 & -0.03 \\
Inflow volume & -0.65 & -0.52 & -0.80 & 0.38 \\
Water level & -0.85 & -0.78 & -0.57 & 0.02 \\
Transparency & -0.94 & -0.92 & -0.57 & 0.04 \\
Water colour & -0.45 & -0.38 & -0.27 & 0.06 \\
Wolf number & 0.83 & 0.75 & 0.74 & -0.33 \\
NAO_year & 0.34 & 0.34 & -0.03 & 0.50 \\
NAO_winter & 0.12 & 0.10 & 0.25 & 0.03 \\
\hline
\end{tabular}

The use of stepwise multiple regression made it possible to identify priority factors of long-term development of phytoplankton. Of all the parameters shown in Table 8, these are transparency, inflow volume, air and water temperature, reservoir level, winter and annual NAO indices $\left(\mathrm{R}^{2}=0.99\right)$, from climatic parameters, these are the Wolf numbers, the mean seasonal air temperature and the annual NAO index $\left(\mathrm{R}^{2}=0.84\right)$; from the regional ones, these are the transparency and the volume of inflow $\left(\mathrm{R}^{2}=0.83\right)$.

\section{Discussion}

The development of phytoplankton in the Rybinsk Reservoir is characterized by significant seasonal and interannual variations, and the $\Sigma \mathrm{CHL}$ content varies within a wide range. The main part of $\Sigma \mathrm{CHL}$ is accounted for by cyanoprokaryotes and diatoms, which corresponds to the taxonomic composition of algocenoses (Korneva, 2015). A significant 
amount of $\mathrm{CHL}_{\mathrm{Cyan}}$ is present during most of the growing season due to an increase in the period of development of cyanoprokaryotes under climate warming (Jeppesen et al., 2005). The low content of $\mathrm{CHL}_{\mathrm{Chl}}$ is consistent with the low amount of CHL $b$ determined by spectrophotometric (Minee- va, 2004) and chromatographic (Breton et al., 2000) methods. The increase in the contribution of $\mathrm{CHL}_{\mathrm{Chl}}$ to $\Sigma \mathrm{CHL}$ in recent years is a sign of an increase in the abundance of green algae, which contain CHL $b$ and periodically enter into the dominant complex of phytoplankton (Korneva, 2015).

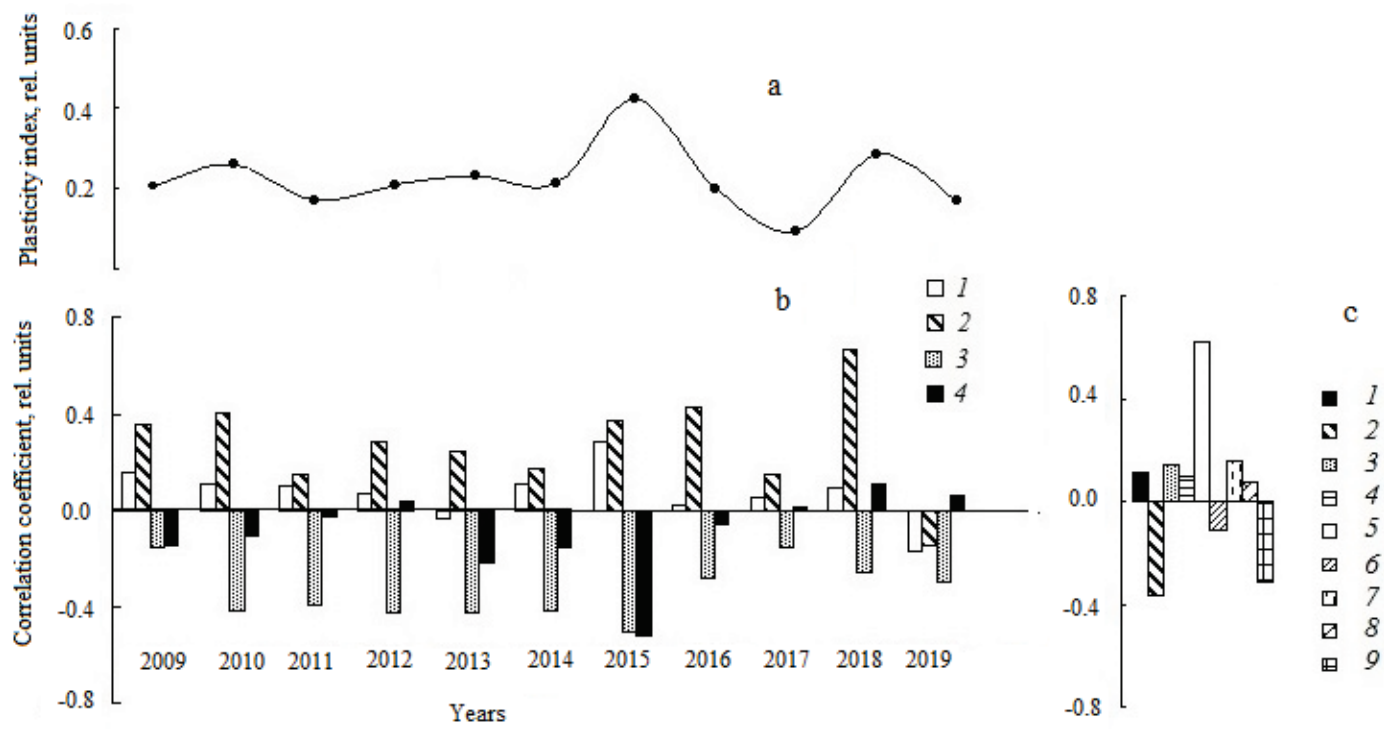

Fig. 4. Change in plasticity index $(a)$ and correlation coefficients $\left(\mathrm{r}_{\mathrm{S}}\right)$ of $\Sigma \mathrm{CHL}$ with abiotic factors in 2009-2019 (b) and in $2010(c)$ : $b$-depth, water temperature, transparency, colour, $1-4$, respectively; $c-\mathrm{NH}_{4}^{+}, \mathrm{NO}_{3}^{-}, \mathrm{TN}, \mathrm{PO}_{4}^{3-}, \mathrm{TP}, \mathrm{BOD}, \mathrm{COD}, \mathrm{Corg}, \mathrm{pH}, 1-9$, respectively; hydrochemical parameters are given in Bikbulatov et al. (2011)

Seasonal dynamics, occurence rate of $\Sigma \mathrm{CHL}$, its maximum and average values, the contribution of the main divisions of algae to the $\Sigma \mathrm{CHL}$ varied over the11-year period depending on temperature conditions and water content (Mineeva, 2016; Mineeva \& Semadeni, 2020). The variability of $\Sigma \mathrm{CHL}$ increased from moderate in 2012 and 2015 to strong and very strong in other years. The coefficients of variation of $\mathrm{CHL}_{\text {Cyan }}$, $\mathrm{CHL}_{\mathrm{Bac}}$, and $\mathrm{CHL}_{\mathrm{Chl}}$ are higher than $\Sigma \mathrm{CHL}$, which corresponds to the idea of a lesser variability of the total as compared to the variability of its constituent parts (Alimov, 1999). The variability of parameters increased under the influence of uncontrolled or unaccounted for factors. The latter was relevant for reservoirs where the development of biological communities was affected not only by local weather conditions and climate, but also by the operating mode of hydraulic engineering structures. Fluctuations of the parameters relative to their average reflect the stability of the ecosystem, which decreases with an increase in the range of fluctuations. The ecosystem of a large artificial moderately eutrophic or eutrophic water body should have low stability, but significant endurance, since it is adapted to seasonal and interannual fluctuations in external conditions (Alimov, 2001). The plasticity index, which is proposed to be used as a measure of stability (Shashulovsky \& Mosiyash, 2010) varied within small limits and was low over the 11-year period. Its minimum value was obtained in 2017 with an extreme inflow volume, a high level and increased colour, while the maximum in 2015 with a small seasonal variability of $\Sigma \mathrm{CHL}$.

The trophic status of the reservoir varied from mesotrophic to moderately eutrophic and eutrophic. Interannual fluctuations in trophic state depending on hydroclimatic factors have been identified for water bodies in different regions (Ruggiu et al., 1998; Kangur et al., 2002; Babanazarova $\&$ Lyashenko, 2007). With the growth of trophic state, the role of the main divisions of algae changed: the absolute concentrations of $\mathrm{CHL}_{\mathrm{Bac}}$, $\mathrm{CHL}_{\mathrm{Chl}}$, and $\mathrm{CHL}_{\mathrm{Cyan}}$ increased, and the relative amount of $\mathrm{CHL}_{\mathrm{Bac}}$ and $\mathrm{CHL}_{\mathrm{Chl}}$ decreased against the background of the growing proportion of

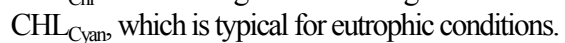

Seasonal development of plankton is an annually repeating process influenced by external factors and internal interactions (Reynolds, 2006). The seasonal variation of chlorophyll in the Rybinsk Reservoir corresponds to the classical model (Sommer et al., 2012) and is characterized by two or three peaks. The timing of their onset, duration, and ratio of values vary in different years. A short spring maximum of $\Sigma \mathrm{CHL}$ with a predominance of $\mathrm{CHL}_{\mathrm{Bac}}$ was recorded in early May - early June in 2011, 2012, 2016, and 2019. Apparently, in other years, it ended before the start of observations due to the earlier opening of the reservoir (Lazareva,
2018), which was a trigger of vegetation in spring forms (Reynolds, 2006). The summer peak, formed by cyanoprokaryotes and diatoms (Korneva, 2015), was insignificant in 2009 and 2017, when the state of the ecosystem was characterized as mesotrophic. The first year, which was not distinguished against the general background by either the temperature regime or the water content conditions, ended the cycle of the decline in the phytoplankton productivity in the reservoir (Lazareva, 2018). Chlorophyll content in the Rybinsk Reservoir, as well as in other reservoirs of the Volga River (Kopylov et al., 2012), was not too large in 2010. However, the conditions of the abnormally hot summer in 2010 were the driving force for the subsequent growth of trophic state and the formation of a prolonged summer phytoplankton maximum with high concentrations of ¿CHL and CHL $_{\text {Cyan }}$ in 2011-2016. Later, in 2017, lower temperatures combined with extreme inflow volumes, limited the mass vegetation of cyanoprokaryotes and the development of the summer maximum.

The autumn peak occurred during a favourable combination of light conditions and supply of the cells with mineral nutrients (Sommer et al., 2012). During the study period, autumn peak was observed in 2014 only, and earlier it was observed in the years with predominance of sunny weather, which ensures the penetration of a sufficient amount of light energy into the water column (Mineeva, 2004). In spring and autumn, with mixing of the water column, which contributes to the maintenance of cells in the suspended state and provides the uptake of nutrients (Yang et al., 2016), diatom peaks are observed in many water bodies of the temperate zone (Reynolds, 2006; Sommer et al., 2012).

Despite the interannual peculiarities of seasonal dynamics and a wide range of values, five stages were distinguished in the seasonal cycle of $\Sigma \mathrm{CHL}$ in the reservoir. Each stage was characterized by homogeneous temperature and transparency, indicating the adaptability of communities to the specific conditions of a certain season. The $\Sigma \mathrm{CHL}$ content within each stage was variable, the average concentrations were higher than their medians, which confirms the complex unaccounted for or uncontrolled external impact on the biota. In large, shallow water bodies that are a dynamic environment, the course of the seasonal succession of phytoplankton is subject to frequent disturbing external effects (Honti et al., 2007, Sommer et al., 2012; Yang et al., 2016). Nonlinear dynamics of average chlorophyll concentrations demonstrate the community's response to changing external conditions and confirms the conclusion about the cyclical nature of these changes. The maximum development of algae is observed in dry years with calm weather, increased insolation and water temperature, and the minimum is observed under opposite conditions 
(Pyrina, 2000; Mineeva 2004; Pyrina et al., 2006). Depending on the characteristics of the water body, the most important factors in the development of phytoplankton can be physical, chemical, or biotic (Chen et al., 2003; Reynolds, 2006; Yang et al., 2016). During the years of the study, we observed a negative correlation of the mean seasonal concentrations of $\Sigma \mathrm{CHL}, \mathrm{CHL}_{\mathrm{Cyan}}$, and $\mathrm{CHL}_{\mathrm{Bac}}$ with the water content parameters (i.e., inflow volume, reservoir level, precipitation amount) limiting the development of phytoplankton. Similar relationships were found for the longterm dynamics of phytoplankton biomass (Korneva, 2015). The average values of $\Sigma \mathrm{CHL}$ and $\mathrm{CHL}_{\text {Cyan }}$ moderately depend on the water temperature, while this effect was not significant for $\mathrm{CHL}_{\mathrm{Bac}}$.

In the presence of weather anomalies, close attention is paid to the temperature factor in the study of aquatic biota (Jeppesen et al., 2005). Temperature does not limit the growth of diatoms, but affects the development of cyanoprokaryotes (Chen et al., 2003), for which the lower temperature limit is $12-16^{\circ} \mathrm{C}$, and the optimal one is $20^{\circ} \mathrm{C}$ and higher (Tryfon \& Moustaka-Gouni, 1997; Tan, 2011). The broad temperature range $\left(5-20{ }^{\circ} \mathrm{C}\right)$, favourable for the diatoms of the Rybinsk Reservoir, corresponds to the vegetation of thermophilic forms in summer, coldloving ones in spring and autumn; for cyanoprokaryotes it is limited to $20-25^{\circ} \mathrm{C}$ (Mineeva, 2016). In the summer of 2010, at the water temperatures $>25^{\circ} \mathrm{C}$, which is not typical of temperate latitudes, $\mathrm{CHL}_{\text {Bac }}$ but not $\mathrm{CHL}_{\mathrm{Cyan}}$, formed the $\Sigma \mathrm{CHL}$ pool, although in southern water bodies the abundant development of cyanoprokaryotes was observed at $30^{\circ} \mathrm{C}$ and above (Chu et al., 2007).

The content of $\Sigma \mathrm{CHL}, \mathrm{CHL}_{\mathrm{Cyan}}$, and $\mathrm{CHL}_{\mathrm{Bac}}$ is negatively related to the water transparency and colour, the characteristics of hydrooptical conditions, which are fundamentally important for the development and photosynthetic activity of phytoplankton (Chen et al., 2003; Reynolds, 2006). At the same time, chlorophyll itself belongs to the optically active components of the aquatic environment and affects the formation of underwater light field, deteriorating its characteristics with excessive development of algae (Mineeva, 2004).

With the complex impact of environmental conditions on the aquatic ecosystem and the difficulties in identifying the main factors, the publications of recent years analyze the relationship of ecosystem indicators with markers of global processes, the NAO index and Wolf numbers (Ottersen et al., 2001; George et al., 2004; Pyrina et al., 2006; Maksimov et al., 2009; Lazareva et al., 2013; Mineeva, 2019). Their influence on the productivity of phytoplankton is considered either as indirect or as integral (cumulative). Correlation analysis is considered the main method for studying this impact on ecological processes (Ottersen et al., 2001).

Comparison of averaged parameters for the growing season revealed positive dependence of $\Sigma \mathrm{CHL}, \mathrm{CHL}_{\mathrm{Cyan}}$, and $\mathrm{CHL}_{\mathrm{Bac}}$ on Wolf numbers, which was previously noted for the long-term dynamics of phytoplankton productivity in different water bodies (Pyrina, 2000; Yevstafiev \& Bondarenko, 2002; Pyrina et al., 2006; Trifonova et al., 2008). A moderate positive correlation, as well as for the pigment characteristics in the Ivankovo and Uglich reservoirs (Mineeva, 2019), was obtained between $\mathrm{CCHL}$, $\mathrm{CHL}_{\mathrm{Cyan}}$ and the annual NAO. The NAO index, Wolf numbers, temperature, and underwater light conditions, as well as the volume of inflow and water level are among the priority factors regulating the long-term dynamics of phytoplankton in the Rybinsk Reservoir.

\section{Conclusion}

In the years with contrasting hydroclimatic conditions and water content (2009-2019), the chlorophyll concentrations in the plankton of the Rybinsk Reservoir varied within a broad range with significant variability of the mean seasonal values, which indicates the low stability of the community. In accordance with the average $\Sigma \mathrm{CHL}$ values, the trophic status of the reservoir was assessed as mesotrophic in 2009 and 2017, eutrophic in 2011-2014, and moderately eutrophic in other years. With an increase in trophy, the concentrations of $\mathrm{CHL}_{\mathrm{Cyan}}, \mathrm{CHL}_{\mathrm{Bac}}$ and the relative content of $\mathrm{CHL}_{\text {Cyan }}$ increased, while the proportion of $\mathrm{CHL}_{\mathrm{Bac}}$ and $\mathrm{CHL}_{\mathrm{Chl}}$ in the $\Sigma \mathrm{CHL}$ fund decreased. In the seasonal cycle of phytoplankton, there were five periods with stable temperature conditions and transparency, but significant variability of $\Sigma \mathrm{CHL}$. The effect of environmental factors on the development of phytoplankton varied in different years. A moderate posi- tive relationship with water temperature and a moderate negative relationship with transparency were seen for the seasonal dynamics of $\Sigma \mathrm{CHL}$. The dependence of $\Sigma \mathrm{CHL}$ on the influence of external factors may be studied in more detail in the long-term aspect. The NAO indices, Wolf numbers, temperature and underwater light conditions, as well as the inflow volume and water level are among the priority factors regulating the long-term dynamics of phytoplankton in the reservoir.

The work was carried out in the framework of the state task of the Ministry of Education and Science of Russia AAAA-A18-118012690096-1. The author is sincerely grateful to T. P. Zaykina for sampling in the field.

\section{References}

Adrian, R., O’Reilly, C. M., Zagarese, H., Baines, S. B., Hessen, D. O., Keller, W., Livingstone, D. M., Sommaruga, R., Straile, D., Van Donk, E., Weyhenmeyer, G. A., \& Winder, M. (2009). Lakes as sentinels of climate change. Limnology and Oceanography, 54, 2283-2297.

Alimov, A. F. (1999). Variabel'nost' produktsionnykh kharakteristik vodnykh ekosistem [Variability of the production characteristics of aquatic ecosystems]. Biologiya Vnutrennikh Vod, 1-3, 70-75 (in Russian).

Alimov, A. F. (2001). Elementy teorii funktsionirovaniya vodnykh ekosistem [Elements of the theory of functioning of aquatic ecosystems]. Nauka, Saint Petersburg (in Russian).

Babanazarova, O. V., \& Lyashenko, O. A. (2007). Inferring long-term changes in the physical-chemical environment of the shallow, enriched Lake Nero from statistical and functional analyses of its phytoplankton. Joutnal of Plankton Research, 29(9), 747-756.

Bertani, I., Primicerio, R., \& Rossetti, G. (2016). Extreme climatic event triggers a lake regime shift that propagates across multiple trophic levels. Ecosystems, 19(1), 16-31.

Bikbulatov, E. S., Bikbulatova, E. M., Bulgakov, N. G., Ershov, Y. V., Konyukhov, I. V., Kopylov, A. I., Korneva, L. G., Lazareva, V. I., Levich, A. P., Litvinov, A. S., Maslennikova, T. S., Mitropolskaya, I. V., Osipov, V. A., Otyukova, N. G., Poddubny, S. A., Pyrina, I. L., Risnik, D. V., Sokolova, E. A., Stepanova, I. E., \& Tselmovich, O. L. (2011). Dannyye sovmestnykh izmereniy biologicheskikh i fiziko-khimicheskikh kharakteristik ekosistemy Rybinskogo vodokhranilishcha [Data from joint measurements of biological and physicochemical characteristics of the ecosystem of the Rybinsk Reservoir]. Maks Press, Moscow (in Russian).

Breton, E., Brunet, C., Sautour, B., \& Brylinski, J.-M. (2000). Annual variations of phytoplankton biomass in the Eastern English Channel: Comparison by pigment signatures and microscopic counts. Journal of Plankton Research, 22(8), 1423-1440.

Canfield, D. E., Bachmann, R. W., \& Hoyer, M. V. (2018). Long-term chlorophyll trends in Florida lakes. Journal Aquat. Plant Manage, 56, 47-56.

Chen, Y., Qin, B., Teubner, K., \& Dokulil, M. T. (2003). Long-term dynamics of phytoplankton assemblages: Microcystis-domination in Lake Taihu, a large shallow lake in China. Journal of Plankton Research, 25(1), 445-453.

Chu, Z., Jin, X., Iwami, N., \& Inamori, Y. (2007). The effect of temperature on growth characteristics and competitions of Microcystis aeruginosa and Oscillatoria mongeotii in a shallow, eutrophic lake simulator system. Hydrobiologia, 581, 217-223.

Gao, N., Ma, Y., Zhao, M., Zhang, L., Zhan, H., Cai, S., \& He, Q. (2020). Quantile analysis of long-term trends of near-surface chlorophyll-a in the Pearl River plume. Water, 12(6), 1662.

George, D. G., Maberly, S. C., \& Hewitt, D. P. (2004). The influence of the North Atlantic Oscillation on the physical, chemical and biological characteristics of four lakes in the English Lake District. Freshwater Biology, 49, 760-774.

Gol'd, V. M., Gayevskiy, N. A., Shatrov, I. Y., Popelnitsky, V. A., \& Rybtsov, S. A. (1986). Opyt ispol'zovaniya fluorestsentsii dlya differentsial'noy otsenki soderzhaniya khlorofilla a u planktonnykh vodorosley [Experience of using fluorescence for differential assessment of chlorophyll a content in planktonic algae]. Gidrobiologicheskiy Zhurnal, 22(3), 80-85 (in Russian).

Honti, M., Istvanovics, V., \& Osztoics, A. (2007). Stability and change of phytoplankton communities in a highly dynamic environment - the case of large, shallow Lake Balaton (Hungary). Hydrobiologia, 581, 225-240.

Jeppesen, E., Sondergaard, M., Jensen, J. P., Havens, K. E., Anneville, O., Carvalho, L., Coveney, M. F., Deneke, R., Dokulil, M. T., Foy, B., Gerdeaux, D., Hampton, S., Hilt, S., Kangur, K., Hler, J., Lammens, E. H. H. R., Lauridsen, T. L., Manka, M., Miracle, M. A. R., Moss, B., Noges, P., Persson, G., Phillips, G., Portielje, R., Romo, S., Schelske, C. L., Straile, D., Tatrai, I., Wille, E., \& Winder, M. (2005). Lake responses to reduced nutrient loading - an analysis of contemporary long-term data from 35 case studies. Freshwater Biology, 50(9), 1747-1771. 
Kangur, K., Milius, A., Mols, T., Laugaste, R., \& Haberman, J. (2002). Lake Peipsi: Changes in nutrient elements and plankton communities in the last decade. Aquatic Ecosystem Health and Management, 5(3), 363-377.

Kopylov, A. I. (2001). Ekologicheskie problemy Verhney Volgi [Ecological Problems of the Upper Volga]. YaGTU, Yaroslavl (in Russian).

Kopylov, A. I., Lazareva, V. I., Mineeva, N. M., Maslennikova, T. S., \& Stroinov, Y. V. (2012). Vliyaniye anomal'no vysokoy temperatury vody na razvitiye planktonnogo soobshchestva vodokhranilishch Sredney Volgi letom 2010 goda [Influence of anomalously high water temperature on the development of the planktonic community of reservoirs in the Middle Volga in the summer of 2010]. Doklady Biological Sciences, 442(1), 133-135 (in Russian).

Korneva, L. G. (2015). Fitoplankton vodokhranilishch basseyna Volgi [Phytoplankton of reservoirs in the Volga basin]. Dom Pechati, Kostroma (in Russian).

Kuzin, B. S. (1972). Rybinskoye vodokhranilishche i yego zhizn' [Rybinsk Reservoir and Its Life]. Nauka, Leningrad (in Russian).

Lamont, T., Barlow, R. G., \& Brewin, R. J. W. (2019). Long-term trends in phytoplankton chlorophyll $a$ and size structure in the Benguela upwelling system. JGR Oceans, 124(2), 1170-1195.

Lazareva, V. I. (2018). Struktura i funktsionirovaniye ekosistemy Rybinskogo vodokhranilishcha v nachale XXI veka [Structure and functioning of the ecosystem in the Rybinsk Reservoir at the beginning of the 21st century]. RAN, Moscow (in Russian).

Lazareva, V. I., Kopylov, A. I., Pyrina, I. L., Sokolova E. A., \& Maslennikova, T. S. (2013). Otklik planktona Rybinskogo vodokhranilishcha na dinamiku SeveroAtlanticheskogo Kolebaniya (North Atlantic Oscillation, NAO) [The response of plankton of the Rybinsk Reservoir to the dynamics of the North Atlantic Oscillation (NAO)]. In: Sovremennyye problemy vodokhranilishch $i$ ikh vodosborov. Trudy Mezhdunarodoi Nauchno-Prakticheskoi Konferentsii. 3. Permskiy Gosudarstvennyi Universitet, Perm. Pp. 145-150 (in Russian).

Maksimov, A. A., Berezina, N. A., Golubkov, S. M., \& Umnova, L. P. (2009). Arkticheskoye kolebaniye i izmeneniya v ekosisteme severnogo ozera [Arctic oscillation and changes in the ecosystem of the northern lake]. Biologicheskiye resursy Belogo morya i vnutrennikh vodoyemov Yevropeyskogo Severa. Materialy 28 Mezhdunarodnoj Konferentsii. KarNTS RAN, Petrozavodsk. Pp. 343 348 (in Russian).

Mineeva, N. M. (2004). Rastitelnyie pigmenty v vode volzhskih vodohranilisch [Plant pigments in the waters of the Volga River reservoirs]. Nauka, Moscow (in Russian).

Mineeva, N. M. (2016). Sezonnaya i mezhgodovaya dinamika khlorofilla v planktone Rybinskogo vodokhranilishcha po dannym fluorestsentnoy diagnostiki [Seasonal and interannual dynamics of chlorophyll in plankton of the Rybinsk Reservoir according to the data of fluorescent diagnostics]. Trudy Instituta Biologii Vnutrennikh Vod RAN, 76, 75-93 (in Russian).

Mineeva, N. M. (2019). Content of photosynthetic pigments in the Upper Volga reservoirs (2005-2016). Inland Water Biology, 12(2), 161-169.

Mineeva, N. M., \& Semadeni, I. V. (2020). Sezonnaya i mezhgodovaya dinamika khlorofilla v planktone Rybinskogo vodokhranilishcha (2015-2019) [Seasonal and interannual dynamics of chlorophyll in plankton of the Rybinsk Reservoir (2015-2019)]. Trudy Instituta Biologii Vnutrennikh Vod RAN, 92, 12-27 (in Russian)

Ottersen, G., Planque, B., Belgrano, A., Post, E., Reid P. C., \& Stenseth, N. C. (2001). Ecological effects of the North Atlantic Oscillation. Oecologia, 128, 1-14.

Özkan, K., Jeppesen, E., Davidson, T. A., Bjerring, R., Johansson, L., Søndergaard, M., Lauridsen, T. L., \& Svenning, J.-C. (2016). Long-term trends and temporal synchrony in plankton richness, diversity and biomass driven by re-oligotrophication and climate across 17 Danish Lakes. Water, 8(10), 427.

Pautova, V. N., \& Rosenberg, G. S. (1999). Fitoplankton Volgi. Ekologiya fitoplanktona Rybinskogo vodokhranilishcha [Phytoplankton of the Volga River. Phytoplankton ecology of the Rybinsk Reservoir]. Samarskiy Nauchnyj Tsentr RAN, Tol'yatti (in Russian).
Pyrina, I. L. (2000). Mnogoletnyaya dinamika i tsiklichnost' mezhgodovykh kolebaniy soderzhaniya khlorofilla v Rybinskom vodokhranilishche [Long-term dynamics and cyclicity of interannual fluctuations in chlorophyll content in the Rybinsk reservoir]. In: Ozernyye ekosistemy: Biologicheskiye protsessy, antropogennaya transformatsiya, kachestvo vody. Materialy mezhdunarodnoi nauchnoj konferentsii. Belorusskiy Gosudarstvennyi Universitet, Minsk, 375-380 (in Russian).

Pyrina, I. L., Litvinov, A. S., Kuchay, L. A., Roshchupko, V. F., \& Sokolova, E. N. (2006). Mnogoletniye izmeneniya pervichnoy produktsii fitoplanktona v Rybinskom vodokhranilishche $\mathrm{v}$ svyazi s deystviyem klimaticheskikh faktorov [Long-term changes in the primary production of phytoplankton in the Rybinsk Reservoir in connection with the action of climatic factors]. Sostoyaniye i problemy produktsionnoy gidrobiologii. KMK, Moscow, $38-46$ (in Russian).

Reynolds, C. S. (2006). The ecology of phytoplankton. Cambridge University Press, Cambridge.

Ruggiu, D., Morabito, G., Panzani, P., \& Pugnetti, A. (1998). Trends and relations among basic phytoplankton characteristics in the course of the longterm oligotrophication of Lake Maggiore (Italy). Hydrobiologia, 369/370, 243-257.

SCOR-UNESCO Working Group 17 (1966). Determination of photosynthetic pigments in sea water. Monographs on Oceanographic Methodology. UNESCO, Montreux. Pp. 9-15.

Shashulovskiy, V. A., \& Mosiyash, S. S. (2010). Formirovaniye biologicheskikh resursov Volgogradskogo vodokhranilishcha v khode suktsessii yego ekosistemy [Formation of biological resources of the Volgograd Reservoir in the process of the succession of its ecosystem]. KMK, Moscow (in Russian).

Sigareva, L. E., Pyrina, I. L., \& Timofeeva, N. A. (2016). Mezhgodovaya dinamika hlorofilla v vode i donnyih otlozheniyah Ryibinskogo vodohranilischa [Interannual chlorophyll dynamics in the water and sediments of the Rybinsk Reservoir]. Trudy Instituta Biologii Vnutrennikh Vod RAN, 76(78), 119-130 (in Russian).

Sommer, U., Adrian, R., De Senerpont Domis, L., Elser, J. J., Gaedke, U., Ibelings, B., Jeppesen, E., Lurling, M., Molinero, J. C., Mooij, W. M., van Donk, E., \& Winder, M. (2012). Beyond the plankton ecology group (PEG) model: Mechanisms driving plankton succession. Annual Review of Ecology, Evolution, and Systematics, 43(7), 429-448.

Tan, X. (2011). Effects of temperature on recruitment and phytoplankton community composition. African Journal of Microbiology Research, 5(32), 5896-5901.

Trifonova, I. S., Makartseva, Y. S., \& Chebotarev, Y. N. (2009). Mnogoletnie izmenenija planktonnykh soobshchestv mezotrofnogo ozera (oz. Krasnoye, Karel'skiy peresheyek) [Long-term changes in the plankton communities of a mesotrophic lake (Lake Krasnoe, Karelian Isthmus)]. In: Biologicheskiye resursy Belogo morya i vnutrennikh vodoyemov Yevropeyskogo Severa. KarNTS RAN, Petrozavodsk. Pp. 570-573 (in Russian).

Tryfon, E., \& Moustaka-Gouni, M. (1997). Species composition and seasonal cycles of phytoplankton with special reference to the nanoplankton of Lake Mikri Prespa. Hydrobiologia, 351, 61-75.

Vtoroy otsenochnyy doklad Rosgidrometa ob izmeneniyakh klimata i ikh posledstviyakh na territorii Rossiyskoy Federatsii (2014) [The second assessment report of Roshydromet on climate changes and their consequences on the territory of the Russian Federation. General summary]. Roshydromet, Moscow (in Russian).

Winder, M., \& Hunter, D. A. (2008). Temporal organization of phytoplankton communities linked to physical forcing. Oecologia, 156, 179-192.

Yang, Y., Pettersson, K., \& Padisák, J. (2016). Repetitive baselines of phytoplankton succession in an unstably stratified temperate lake (Lake Erken, Sweden): A long-term analysis. Hydrobiologia, 764(1), 211-227.

Yevstaf'yev, V. K., \& Bondarenko, N. A. (2002). Priroda yavleniya "melozimykh" let $v$ oz. Baykal [The nature of the phenomenon of soft winters years in the Lake Baikal]. Gidrobiologicheskiy Zhurnal, 38(1), 3-12 (in Russian). 